\title{
Lagged Country Returns and International Stock Return Predictability during Business Cycle Recession Periods
}

\author{
Yi-Chieh Wen ${ }^{\mathrm{a}}$ and Bin $\mathrm{Li}^{\mathrm{b}}{ }^{\mathrm{b}}$ \\ ${ }^{a}$ Department of Accounting Information, National Taichung University of Science and \\ Technology, Taichung, Taiwan \\ ${ }^{b}$ Griffith Business School, Griffith University, Nathan, QLD 4111, Australia
}

\begin{abstract}
This study examines stock return predictability in business cycle fluctuations across 17 developed countries and 26 developing countries over the period from January 1970 to December 2019. We uncover that lagged U.S. returns can be regarded as a reliable predictor only during recessions. The results remain robust after controlling for commonly used return predictors. Our empirical findings carry some implications for the role of leading markets, fundamental uncertainty, change in investors' beliefs and dynamics of stock return volatility in economic downturns.
\end{abstract}

Keywords: Return predictability, Recession, Lagged country returns, Business cycle JEL Classification: G15

\footnotetext{
* Corresponding author: Department of Accounting, Finance and Economics, Griffith Business School, Griffith University, Queensland 4111, Australia. E-mail: b.li@griffith.edu.au; Tel: +61 737357117.
} 


\section{Introduction}

The elusive return predictability in international stock markets with important implications for asset pricing (Korajczyk and Viallet, 1989; Campbell and Hamao, 1992; Griffin, 2002; Schrimpf, 2010), hedging and investment is of particular interest to both practitioners and academics. Predicting future returns may be becoming more exposed to global economic scenarios. Dahlquist and Hasseltoft (2013) suggest that the global factor is closely linked to U.S. economic contractions. Extant research shows that information on market price and volatility can potentially spillover from the U.S. to many non-U.S. countries, indicating that the U.S. plays a leading role in international financial markets (Bollerslev, Marrone, Xu, and Zhou, 2013; Rapach, Strauss, and Zhou, 2013; Nyberg, and Pönkä, 2016).

Kim, Shamsuddin and Lim (2011) point out that return predictability is driven by the extreme degree of economic uncertainty and dynamic market conditions. Recently, Aye, Balcilar, and Gupta (2017) employ various models to examine the role of U.S. returns on timevarying effects for 11 industrialized countries. They confirm that U.S. stock return has significant predictive power for all the countries over specific periods. Cujean and Hasler (2017) build a theoretical model and document that counter-cyclical pattern of investors' disagreement (Carlin, Longstaff, and Matoba, 2014) move return predictability to concentrate in poor economic conditions. The disagreement stems from model heterogeneity (Kandel and Pearson, 1995), causing investors to revise their expectations rapidly in the midst of recessions. Andrei, Carlin and Hasler (2019) also provide a theoretical mechanism of disagreement and structural uncertainty about the length of business cycles. The persistence of fundamentals has higher stock return volatility during recession periods. Empirically, Rapach, Strauss and Zhou (2013) examine predictive models of stock returns including lagged U.S. returns for 10 non-U.S. countries and find that forecasting stock gains seem to be reflected in National Bureau of Economic Research (NBER) recessions. Siliverstovs (2017) demonstrates the asymmetric phenomenon in predictive power of the lagged U.S. returns across business cycles, lending 
strong support to the significance of lagged U.S. returns in the predictability of stock returns, particularly in recessions.

Empirical evidence on the predictive power of macroeconomic and financial variables for stock returns is still inconclusive. Karolyi and Stultz (1996) argue that monthly unexpected changes in macroeconomic variables have less information content of stock returns. Although macroeconomic variables seem to offer good explanations of potential equity market risk factors that can affect expected returns or market volatility (Flannery and Protopapadakis, 2002), they are difficult to establish consistent indicators across countries. In terms of traditional valuation measures or financial ratios for dividends and earnings, they possess little forecasting power for international returns due to variations in expected returns (Lettau and Van Nieuwerburgh, 2008; Hjalmarsson, 2010) or measurement changes (Lettau and Ludvigson, 2010). However, some studies find that certain variables such as interest rates or lagged U.S. returns are observed to have predictive power across countries (Rapach, Wohar, and Rangvid, 2005; Ang and Bekaert, 2007; Rapach, Strauss, and Zhou, 2013; Nyberg, and Pönkä, 2016). Above all, there is no conclusive evidence as to which return predictor is the best due to the emerged conflicting results, leaving this empirical question open in the international finance literature.

Motivated by some theoretical standpoints and empirical evidence regarding asset pricing and predictive models over the business cycle, we investigate whether lagged U.S. returns work better as a more effective predictor during NBER recessions in international stock markets. As mentioned above, the U.S. is the world's largest economy, which signals an important source of global factor on international return predictability. The volatility of international stock returns is influenced by global factors and it tends to rise during recessions (Schwert, 1989; Dahlquist and Hasseltoft, 2013). Estrella and Mishkin (1998) suggest that stock price indices emerge as a useful and simple financial indicator in predicting U.S. 
recessions. Nyberg (2013) points out that the understanding of the transition between recessions and expansions can determine the state of the U.S. stock market.

We mainly examine return predictability using lagged country returns (including lagged U.S. returns and lagged own country returns) over recession periods for 17 developed countries and 26 developing countries. When the recession indicator is not included in our analysis, we find little evidence that lagged U.S. returns can serve as a powerful predictor for both developed and developing stock markets over the whole sample period. Lagged own country returns also have very limited ability to predict future stock returns. Our sample period spans a long period, from January 1970 to December 2019. It is possible that the patterns of stock return predictability will evolve over time. To verify the time-varying effects, we divide the full sample into eight sub-samples based on the inclusion of recession and expansion periods to perform our predictive analyses. We uncover that the predictive results of lagged U.S. returns come to a similar and weaker conclusion across eight different horizons for 17 developed countries. Overall, the lagged U.S. returns and the lagged own country returns still show little and inconsistent predictive ability.

When considering the interactions of lagged U.S. returns with recession index in predictive regression models, however, there is strong evidence of return predictability for 17 developed markets and 26 developing markets. Moreover, lagged U.S. returns predict future returns in many other countries better than lagged own country returns. Under this scenario, our results are consistent with Rapach, Strauss and Zhou (2013) and Nyberg, and Pönkä (2016). The lagged U.S. returns can be regarded as a robust predictor in international equity markets but only during recession periods. These results are also in line with those documented in recent research (Siliverstovs, 2017; Cujean and Hasler, 2017; Andrei, Carlin and Hasler, 2019), who find that the predictability of stock returns seems to concentrate in the midst of NBER recessions. Some possible explanations for the existence of return predictability during recessions include adaptive markets hypothesis (Lo, 2004, 2005), revisions in investors' beliefs 
(Timmermann, 2008), counter-cyclical investors' disagreement (Carlin, Longstaff, and Matoba, 2014; Cujean and Hasler, 2017) and structural uncertainty (Andrei, Carlin and Hasler, 2019). Further, Campbell and Hentschel (1992) explain the phenomenon of predictive asymmetry that negative returns generate higher volatility than positive returns. We know that the U.S. recessions are related to some unusual events, such as market crash, fundamental crises and economic bubbles, causing the U.S. and other international markets to incur losses and negative returns. Thus, we replace recession index with extreme returns to examine the predictive power of lagged U.S. returns with negative values and the lowest $10 \%$ quantile of returns for developed countries. We report weak or no evidence of predictability with respect to the interactions between the lagged U.S. returns and extreme returns. One possible explanation for this finding is that large negative returns may only reflect the effects of some major events rather than the business cycles per se. These events have no direct and important impact on stock markets for non-U.S. countries, and thus U.S. negative or extreme returns provide little predictive information in international markets.

The primary contributions of our paper to the extant literature are three-fold. First, we supplement the empirical literature on international return predictability by including more countries and considering the business cycle to forecast stock returns in a long period. We investigate the predictability of stock returns using lagged country returns during NBER recessions for 17 developed markets and 26 developing markets over the period 1970-2019. In addition, we also examine the information content of negative or extreme returns (event shocks of the business cycles) on return predictability. As a whole, our results are more robust and in line with recent studies. Second, we find that lagged U.S. returns significantly predict stock returns in many non-U.S. countries only during recessions, but lagged own country returns, the dividend yield of the U.S. market, three-month U.S. Treasury-bill rate and changes in oil prices possess very limited predictive power. We attempt to search for a better leading indicator in the international context because the predictive ability of macroeconomic and financial 
variables is far from univocal. Lagged U.S. returns play a reliable indicator across different countries after controlling for other predictors. Finally, in terms of return predictability in international stock markets, our study sheds light on the potentially important issues regarding the role of leading markets, fundamental uncertainty, change in investors' beliefs and dynamics of stock return volatility during economic downturns.

The rest of the paper is organized as follows. Section 2 outlines the data and methodology. Section 3 provides the empirical findings and robustness checks. Section 4 concludes.

\section{Data and Methodology}

\subsection{Data}

Our empirical data mainly relies on the Morgan Stanley Capital International (MSCI) monthly stock returns of 17 developed countries covering the period from January 1970 to December 2019, including several expansion and recession periods. The monthly returns are calculated using daily total return indices of each country's stock market based on both local currency and U.S. dollars. Further, we analyze the predictability of international stock returns for 26 developing countries ${ }^{1}$. The sample of several developing countries is constrained in part by period and data availability. We also gather financial and macroeconomic data for control variables. Three-month U.S. Treasury-bill rate is obtained from French's Data Library, while the dividend yield of the U.S. market is extracted from Robert Shiller's website. We collect stock returns and oil prices from DataStream.

Fama and French (1989) argue that when economic conditions are poor, future expected stock returns must be high to lure investors into the market. Some recent studies suggest that the predictability of stock returns is driven by the structural uncertainty or economic recessions.

\footnotetext{
${ }^{1}$ The sample period for 26 developing markets is from January 1988 to December 2019, but the starting sample dates may vary for some markets due to the availability of data. Additionally, though Finland and New Zealand are developed markets, their data starting date is 1988; we thus put them in the group of developing countries.
} 
Thus, we include an indicator of the NBER business cycles to distinguish the state of the economy and focus on the predictability of stock returns during U.S. recessions. The NBER recession indicator data come from the Federal Reserve Economic Data. We extend the results of Rapach, Strauss and Zhou (2013), Nyberg, and Pönkä (2016) and Siliverstovs (2017) to examine whether lagged U.S. returns can be viewed as a more useful predictor of stock returns in economic downturns.

Table 1 provides the summary statistics of the monthly returns across 17 developed markets for the whole sample period. For ease of comparison, all returns are measured in U.S. dollars. The mean monthly returns vary across countries with the largest of $1.1 \%$ for Hong Kong and the lowest of $0.4 \%$ for Italy. Hong Kong also has the highest standard deviation (volatile) while Switzerland has the lowest standard deviation (stable). The skewness, kurtosis and Jarque-Bera test suggests that the monthly returns are not normally distributed. Most of return series are presented to be left skewed (except the U.K.) and leptokurtic. Most of the firstorder autocorrelation coefficients are less than 0.1. The low values of Ljung-Box statistics for lag $20\left(Q_{20}\right)$ indicate that no serial correlation left in the residuals. In addition, we report the correlations of the 17 developed markets with the U.S. market returns. Table 1 shows that the highest correlation is the one with the Canadian market at 0.747 and the lowest correlation is the one with Japan at 0.387 . For markets such as Austria, Denmark, Hong Kong, Italy, Japan, and Spain, their return correlation with the U.S. is less than 0.5. Finally, this table also displays the median, minimum, maximum, the $10^{\text {th }}$ percentile $(10 \%)$ and the $90^{\text {th }}$ percentile $(90 \%)$ of monthly returns for each country.

\section{[Table 1 about here]}

\subsection{Methodology}

The primary focus of our study is to examine whether lagged country returns are useful predictors during U.S. recession periods for 17 developed stock markets, particularly lagged U.S. returns. On account of the leading role of the U.S. equity market, it is important to 
understand the impacts of information diffusion regarding global macroeconomic fundamentals on future stock returns from the U.S. to other industrialized countries. Thus, it is of interest to capture the relationship between the business-cycle predictor and time-varying stock return.

First, we perform a predictive regression framework that relies on a lead-lag relationship to analyze the predictive ability of lagged country returns. Our regression models are specified as follows:

$$
\begin{aligned}
& R_{i, t+1}^{o w n}=\alpha_{i}+\beta_{i} R_{i, t}^{o w n}+\varepsilon_{i, t+1} \\
& R_{i, t+1}^{o w n}=\alpha_{i}+\beta_{i} R_{t}^{U S}+\varepsilon_{i, t+1} \\
& R_{i, t+1}^{o w n}=\alpha_{i}+\beta_{i} R_{i, t}^{o w n}+\gamma_{i} R_{t}^{U S}+\varepsilon_{i, t+1}
\end{aligned}
$$

In Equations (1) and (2), this analysis is tested by estimating the model separately for lagged own country returns and lagged U.S. returns. $R_{i, t+1}^{o w n}$ is the one-month-ahead monthly market return for country $i$. We delineate $R_{i, t}^{o w n}$ as lagged own country returns in month $t$ for country i. $R_{t}^{U S}$ denotes lagged U.S. market return in month $t . \varepsilon_{i, t+1}$ is an error term. The predictive power of lagged country returns may change over time due to time-varying volatility risk (Aye, Balcilar, and Gupta, 2017). We further examine eight sub-sample periods to understand whether the predictive power is stable based on a model including both lagged country returns as shown in Equation (3).

Second, the extant studies point out that stock returns are more volatile and risk premia should be higher during recessions than expansions (Fama and French, 1989; Nyberg, 2011; Lustig and Verdelhan, 2012). The predictability of stock returns seems to exist in the bad times of business cycles (Garcia, 2013; Cujean and Hasler, 2017). In light of recent empirical studies (Rapach, Strauss and Zhou, 2013; Siliverstovs, 2017) ${ }^{2}$, we use a recession variable $\left(\operatorname{Rec}_{t}\right)$ in

\footnotetext{
${ }^{2}$ Rapach, Strauss and Zhou (2013) show out-of-sample $\mathrm{R}^{2} \mathrm{~s}$ in recession periods using graphs, while Siliverstovs (2017) tests the significance of out-of-sample $\mathrm{R}^{2} \mathrm{~s}$ by dividing the sample into recession and expansion periods.
} 
Equation (4) to test the predictive power of lagged U.S. returns with recession signals.

$$
R_{i, t+1}^{o w n}=\alpha_{i}+\beta_{i} R_{t}^{U S}+\gamma_{i} R_{t}^{U S} \times \operatorname{Rec}_{t}+\varepsilon_{i, t+1}
$$

where $R e c_{t}$ is an indicator variable that takes a value of one if the U.S. economy belongs to an NBER recession in month $t$, and 0 otherwise. ${ }^{3}$ When the coefficient $\left(\gamma_{i}\right)$ on the interaction term between $R_{t}^{U S}$ and $R e c_{t}$ is statistically different from zero, we can capture the significant predictive power of lagged U.S. returns during U.S. recessions in international stock markets.

On the other hand, we are also interested in exploring the role of U.S. economic fundamentals in predicting stock returns of non-U.S. countries. Previous empirical findings suggest that certain financial and macroeconomic variables such as short-term interest rate, dividend yield, the lagged stock returns and changes in oil prices are the most commonly used predictors of stock returns across countries (Rodriguez, Restoy and Pena, 2002; Rapach, Wohar and Rangvid, 2005; Ang and Bekaert, 2007; Hjalmarsson, 2010; Rapach, Strauss and Zhou, 2013; Nyberg and Pönkä, 2016; Siliverstovs, 2017). To reinforce the interpretation of return predictability using lagged U.S. returns during recessions, four forecasting variables also taken into consideration include the lagged own country returns $\left(R_{i, t}^{o w n}\right)$, the dividend yield of the U.S. market $\left(D Y_{t}\right)$, U.S. three-month Treasury-bill rate $\left(T B_{t}\right)$ and changes in oil prices $\left(d O i l_{t}\right)$. The regression equation is given as follows:

$$
R_{i, t+1}^{o w n}=\alpha_{i}+\beta_{i} R_{t}^{U S}+\gamma_{i} R_{t}^{U S} \times \operatorname{Rec}_{t}+\delta_{i} R_{i, t}^{o w n}+\theta_{i} D Y_{t}+k_{i} T B_{t}+\lambda_{i} d O i l_{t}+\varepsilon_{i, t+1}
$$

Third, most of the U.S. recessions were caused by economic and financial events, which can lead to substantial revisions in expected stock returns and cash flows regarding the negative shocks. It is possible to observe that the recessions can explain this link between negative

As our focus is on in-sample predictability to demonstrate that the predictability mainly lies in the recession periods, we use the dummy variable approach.

${ }^{3}$ In our additional test, we take into consideration the publication lag of the NBER recession indicator, which is assumed to be two months. We run the following regression model: $R_{i, t+1}^{\text {own }}=\alpha_{i}+\beta_{i} R_{t}^{U S}+\gamma_{i} R_{t}^{U S} \times \operatorname{Rec}_{t-2}+$ $\varepsilon_{i, t+1}$ to check the predictive power of lagged U.S. returns in recessions using a lag of two months. Our result is quite similar to the one presented in Panel A of Table 4. The results also hold for the assumption of one-month publication lag. 
returns and stock volatility. We have shown that the stock return distributions for 17 developed markets have non-normality and negative skewness in Table 1. As argued by Campbell and Hentschel (1992), negative returns lead to larger volatility than positive returns. Therefore, we consider the predictive effect of lagged U.S. returns with negative values and extreme returns (the lowest $10 \%$ quantile of returns). Our regression models take the following form,

$$
\begin{aligned}
& R_{i, t+1}^{\text {own }}=\alpha_{i}+\beta_{i} R_{i, t}^{\text {own }}+\gamma_{i} R_{t}^{U S}+\delta_{i} R_{t}^{U S} \times \operatorname{Neg}_{t}+\varepsilon_{i, t+1} \\
& R_{i, t+1}^{\text {own }}=\alpha_{i}+\beta_{i} R_{i, t}^{\text {own }}+\gamma_{i} R_{t}^{U S}+\delta_{i} R_{t}^{U S} \times \operatorname{Low}_{t}^{10}+\varepsilon_{i, t+1}
\end{aligned}
$$

where $\mathrm{Neg}_{t}$ denotes an indicator variable equal to one when the lagged U.S. returns is negative in month $t$ and 0 otherwise. In Equation (6), we explore the predictive power of lagged U.S. negative returns across different countries based on the coefficient of the interaction terms between $R_{t}^{U S}$ and $\mathrm{Neg}_{t}$. Further, we focus on the lowest $10 \%$ quantile of returns to understand the predictive differences in extreme returns. In Model (6) and Model (7), we use two dummy variables which equal one if U.S. returns are negative values $\left(\mathrm{Neg}_{t}\right)$ and the lowest $10 \%$ quantile of returns $\left(\operatorname{Low}_{t}^{10}\right)$ in month $t$, respectively.

\section{Empirical Results}

\subsection{Return Predictor Using Lagged Country Returns}

We examine the predictive power of lagged country returns (including $R_{i, t}^{o w n}$ and $R_{t}^{U S}$ ). In Table $2^{4}$, our results show that lagged own country returns and lagged U.S. returns separately affect 7 of the 17 non-U.S. countries over the whole sample period. The predictive ability of lagged own country returns and lagged U.S. returns both exist in Austria, Japan and Switzerland. Thus, lagged U.S. returns do not seem to be regarded as a powerful return predictor when the U.S. market returns include the good and bad states. Moreover, this

\footnotetext{
${ }^{4}$ We also run Equation (3) by including two lagged country returns for the full sample. Untabulated results again confirm a weaker prediction.
} 
predictor $\left(R_{t}^{U S}\right)$ is not better than the lagged own country returns $\left(R_{i, t}^{\text {own }}\right)$ in international equity markets, which is inconsistent with Rapach, Strauss and Zhou (2013).

\section{[Table 2 about here]}

To further test whether our results are driven by the time-varying effect, we perform a sub-period analysis by choosing sub-sample periods of different window lengths based on the inclusion of recession and expansion periods that are observed in the NBER business cycle. The sub-samples are $1970 \mathrm{~m} 1$ to $1993 \mathrm{~m} 12$ (first half), $1994 \mathrm{ml}$ to $2019 \mathrm{~m} 12$ (second half), $1970 \mathrm{~m} 1$ to $1979 \mathrm{~m} 12$ (first decade), $1980 \mathrm{~m} 1$ to $1989 \mathrm{~m} 12$ (second decade), $1990 \mathrm{~m} 1$ to $1999 \mathrm{~m} 12$ (third decade), $2000 \mathrm{~m} 1$ to $2009 \mathrm{~m} 12$ (fourth decade), $2010 \mathrm{~m} 1$ to $2019 \mathrm{~m} 12$ (fifth decade), and 1970m1 to 2006m12 (before the Global Financial Crisis (GFC)).

Table 3 reports the predictive results using lagged country returns for 17 developed markets. We find that many non-U.S. markets cannot be significantly predicted by lagged own country returns and lagged U.S. returns across different sub-periods. For these eight subperiods, the return predictability is quite weak, particularly in the second half(1994-2019), first decade (1970-1979) and fourth decade (2000-2009). In the first half (1970-1993), fifth decade (2010-2019) and the sample period before the GFC (1970-2006), though lagged country returns display limited predictive ability, we can observe that lagged U.S. returns, as compared to lagged own country returns, have a significant impact on future stock returns for several nonU.S. developed markets. However, in the second decade (1980-1989), third decade (1990-1999) and fourth decade (2000-2009), lagged own country returns seem to show a larger effect on return predictability than lagged U.S. returns. Overall, our results indicate less and inconsistent return predictability for lagged country returns; the evidence of predictability for many countries even disappears when distinguishing different sample periods.

[Table 3 about here]

\subsection{Stock Return Predictability during NBER Recessions}


The behaviors of asset prices across business cycles reflect economic conditions and investors' beliefs. Previous research by Ozoguz (2009) documents that change in investors' beliefs and uncertainty for economic fundamentals can explain the time-variation in investment opportunities and predict future stock returns. Furthermore, the U.S. economy has experienced several major recessions in its history that precipitate world economic fluctuations and stock market volatility, particularly in the 19th century. Hence, U.S. market returns also act as an important predictor for international stock returns.

Rapach, Strauss and Zhou (2013) find that predictive power of lagged U.S. returns for 9 of the 10 non-U.S. countries is concentrated in business cycle recessions (the coefficients are significant at the 10\% level). As documented by Siliverstovs (2017), lagged U.S. returns have asymmetric effects on return predictability depending on the state of the economy. During the recessions there is strong evidence of predictive power of lagged U.S. returns in 10 industrialized countries.

To gain insight into return predictability considering the influence of the U.S. market fundamentals across countries, we examine whether the predictive power of lagged U.S. returns varies during the recession periods. We add an indicator variable based on NBER recession dates and include the interaction terms with lagged U.S. returns in the regressions. If the bad times of business cycle are the driving force of risk premia, we would expect to find a statistically significant predictor in international return predictability. As shown in Panel A of Table 4, most of the coefficients on the interaction terms of lagged U.S. returns with recession indicator are significantly positive. Newey-West (1987) heteroskedasticity and autocorrelation consistent standard errors with 12 lags are used to compute robust $t$-statistics. ${ }^{5}$ We find that

\footnotetext{
${ }^{5}$ Following most studies, we report Newey-West $t$-statistics using fixed lags (12 months in our paper). In a recent paper, Lazarus, Lewis, Stock and Watson (2018) recommend to use lags which vary with sample size (number of lags $=1.3 \mathrm{~T}^{1 / 2}$, where $\mathrm{T}$ is the time-series sample size; see Equation (3) in their paper) in Newey-West tests for the balance of size distortion and power loss. However, the fixed-b critical values used in their recommendation is nonstandard, but can be derived using Table 1 in Kiefer and Vogelsang (2005). We also conduct such a test following their recommendation, and find very similar results (results are not shown here to conserve space).
} 
only 3 of 17 coefficients on the interactions $\left(R_{t}^{U S} \times R e c_{t}\right)$ are insignificant, including those in Austria, Norway and Sweden. Our results suggest that in the midst of recessions, there is strong evidence of predictability using lagged U.S. returns across different developed markets.

Our results provide supporting evidence for the predictive power of lagged U.S. returns during NBER recessions. However, previous studies also find some financial or macroeconomic variables are widely used to predict stock returns, but their empirical results are quite mixed. We thus further explore whether our main results are robust when adding additional predictors in our regression model including the lagged own country returns $\left(R_{i, t}^{o w n}\right)$, the dividend yield of the U.S. market $\left(D Y_{t}\right)$, U.S. three-month Treasury-bill rate $\left(T B_{t}\right)$ and changes in oil prices $\left(d_{O i l}\right)$. As seen in Panel B of Table 4, the results show that lagged U.S. returns are still a robust predictor, but the results are solely driven by the recession periods. As documented by the recent works (Rapach, Strauss and Zhou, 2013; Cujean and Hasler, 2017; Siliverstovs, 2017; Andrei, Carlin and Hasler, 2019), our results lend some support to the view of better return predictability during recessions.

However, one may raise a concern of the multicollinearity issue in Equation (5) as it includes both the lagged own country returns and lagged U.S. returns, which have been shown to have high correlations in Table 1. Although the lagged own country returns and U.S. returns are highly correlated, the predictive ability of lagged U.S. returns during recession periods come to a similar but slightly stronger conclusion when the lagged own country returns are removed from Equation (5). Our untabulated results indicate that only 3 of 17 coefficients on the interactions $\left(R_{t}^{U S} \times R e c_{t}\right)$ are also insignificant. Further, we obtain the monthly orthogonalized lagged own country returns from the residual component of the model $R_{i, t}^{\text {own }}=$ $\alpha_{i}+\beta_{i} R_{t}^{U S}+\varepsilon_{i, t}$ to predict monthly stock returns. The orthogonalized lagged own country return (uncorrelated from the lagged U.S. returns) is used in the regression model in place of $R_{i, t}^{\text {own }}$. The results (not shown here) are similar and thus we conclude that our results are not affected by the multicollinearity. 
Some studies have addressed issues of instability of return prediction models and parameter uncertainty underpinned by a theoretical perspective (Campbell and Hamao, 1992; Avramov, 2002; Paye and Timmermann, 2006; Schrimpf, 2010). We attempt to explore the possible explanations behind the existence of return predictability during recessions. Stock returns arise from the change in prices and liquidity needs, reflecting the environmental conditions, macroeconomic shocks and revisions in investors' beliefs (Timmermann, 2008). The evolution of return predictability seems to vary over time and across markets, which implies that market participants will adjust rapidly to new information and economic conditions, as suggested by Lo's $(2004,2005)$ adaptive markets hypothesis.

The average excess returns and Sharpe ratios tend to increase during recessions due to time-varying risk premia (Pesaran and Timmermann, 1995; Lustig and Verdelhan, 2012). In recession periods, stock markets show low-return and high-volatility phenomena, and the behavior and psychology of investors during those periods may significantly affect the pattern of stock returns. Cujean and Hasler (2017) find that return predictability in the midst of recessions can be caused by counter-cyclical investors' disagreement, which stems from model heterogeneity regarding investors' learning speed in the persistence of business cycles. Timmermann (1993) and Andrei, Carlin and Hasler (2019) also point out that investors' learning regarding the persistence of fundamentals can explain the increasing volatility and return predictability, mostly in the period of economic recessions. Our results can be explained by the theoretical linkages between the fluctuations in economic uncertainty and stock risk premia, which drive time-varying expected returns due to investors' heterogeneous beliefs and historical information.

\section{[Table 4 about here]}

\subsection{The Predictive Ability of U.S. Negative or Extreme Returns}

We observe that U.S. recessions are associated with a series of unusual events, including the market crash in 1987, fundamental crises (e.g., oil shock and sub-prime mortgage) 
and economic bubbles (e.g., dot.com and U.S. housing). These events cause the U.S. and other international equity markets to suffer huge losses and sustain large negative returns. As emphasized previously, the U.S. financial markets play a leading role in the world economy and have the effect of generating a gradual information diffusion. Stock markets are sensitive to adverse economic conditions. This means that negative returns exhibit very high volatility more than the same magnitude of positive returns (Campbell and Hentschel, 1992; Aloui, Ben Aissa and Nguyen, 2011). When the volatility increases, expected future stock returns seem to increase, implying that stock returns may have predictive content (Campbell and Hamao, 1992; Lin, Engle and Ito, 1994). Thus, we substitute the negative return indicator for the recession indicator to examine the predictive power of negative stock returns across countries.

In Panel A of Table 5, we present return predictability using lagged U.S. returns with negative values for 17 developed countries. Specifically, the coefficients on the interaction terms of lagged U.S. returns with negative values $\left(R_{t}^{U S} \times N e g_{t}\right)$ generate less significant results; only 2 of 17 time-series regressions (Netherlands and Norway) have significant coefficients. We also find that the predictive power of lagged own country returns and lagged U.S. returns seem quite weak; only 1 of 17 countries has a significant coefficient at the $10 \%$ level.

Further, we test the lowest $10 \%$ quantile of returns $\left(\operatorname{Low}_{t}^{10}\right)$ that it is most likely to reflect negative returns. $L o w_{t}^{10}$ refers to a dummy variable that takes the value of one if U.S. returns are in the lowest $10 \%$ return quantile, and zero otherwise. Panels B of Table 5 shows the interaction effect of lagged U.S. returns with the extreme returns $\left(R_{t}^{U S} \times L o w_{t}^{10}\right)$. This result can be interpreted similar to negative returns. Only Netherlands and Norway remain significant at the $5 \%$ level.

Overall, our findings suggest that there is no strong evidence of return predictability when we use the U.S. negative or extreme return indicator in place of the U.S. recession indicator. One possible explanation for the relative lack of significant predictability is that 
negative or extreme returns originated from certain events are irrelevant to the effect of business cycles. Given that these events have no direct and important influence on stock markets in non-U.S. countries, U.S. negative or extreme returns may provide little predictive content.

\section{[Table 5 about here]}

\subsection{Additional Robustness Checks}

We have performed empirical analyses using lagged country returns to predict future returns for 17 developed markets. Our main results suggest that lagged U.S. returns serve as a powerful indicator to predict international stock returns in NBER recessions. Moreover, we examine whether the predictive power of lagged U.S. returns still hold for developing countries. Based on Equation (3), we investigate the predictive ability of lagged country returns for 26 developing markets over the period from January 1988 to December 2019. As displayed in Panel A of Table 6, the result is significantly weaker for the predictive model including lagged U.S. returns and lagged own country returns. We then build the following equation to examine the recession states on return predictability. As expected, Panel B of Table $6^{6}$ demonstrates very similar findings to those in Panel A of Table 4.

$$
R_{i, t+1}^{\text {own }}=\alpha_{i}+\beta_{i} R_{i, t}^{\text {own }}+\gamma_{i} R_{t}^{U S}+\delta_{i} R_{t}^{U S} \times R E C_{t}+\varepsilon_{i, t+1}
$$

Further, to verify the predictive ability of lagged U.S. returns with recession signals, we also include three potential predictors in Equation (8): the dividend yield of the U.S. market $\left(D Y_{t}\right)$, U.S. three-month Treasury-bill rate $\left(T B_{t}\right)$ and changes in oil prices $\left(d O i l_{t}\right)$. In untabulated analysis, we find that the coefficients on the interaction $\left(R_{t}^{U S} \times R e c_{t}\right)$ remain positive and are highly significant in 18 of 26 international markets. Akin to our prior results in Panel B of Table 4, three additional predictors and lagged own country returns $\left(R_{i, t}^{\text {own }}\right)$ have

\footnotetext{
${ }^{6}$ Similarly, when the lagged own country returns are removed in Equation (8), we also find that the coefficients on the interaction term $\left(R_{t}^{U S} \times \operatorname{Rec}_{t}\right)$ remain strongly significant. Our results do not suffer from the multicollinearity issue.
} 
very limited predictive power over the variation of the international stock returns. Collectively, our results illustrate the notion that return predictability is driven by the conditions of U.S. business cycles and dynamics of stock return volatility.

Stock returns across international markets denominated in U.S. dollar or local currency may yield different results. For comparison, we repeat our all analyses using local currency returns to examine the robustness of our empirical findings. In untabulated results, similar patterns emerge with respect to the predictive power of lagged U.S. returns in recessions.

\section{[Table 6 about here]}

\section{Conclusions}

This paper is motivated by some theoretical grounds and empirical evidence with respect to asset pricing and predictive models over business cycles. We extend the empirical works of Rapach, Strauss and Zhou (2013), Nyberg, and Pönkä (2016) and Siliverstovs (2017) by examining international return predictability in NBER recessions. We use lagged country returns (including lagged U.S. market returns and lagged own country returns) to predict future returns across 17 developed countries and 26 developing countries during the period from January 1970 to December 2019. Our results suggest that lagged U.S. returns can be regarded as a superior leading predictor only during NBER recessions, consistent with the theoretical arguments of Andrei, Carlin and Hasler (2019) and Cujean and Hasler (2017).

In addition, most of the U.S. recessions are associated with economic and financial events, causing international equity markets to generate larger negative returns and higher volatility. Therefore, we test the predictive effect of lagged U.S. returns with negative values or extreme returns (the lowest 10\% quantile of returns). Our results show that U.S. negative returns or extreme returns provide very little predictive content because certain events may have no substantial influence on stock markets in non-U.S. countries.

We draw a similar conclusion that return predictability is driven by the business cycle recessions and dynamics of stock return volatility due to change in investors' beliefs and 
uncertainty for the state of the economy. As emphasized by Schrimpf (2010), international return predictability cannot be entirely taken as a uniform feature and a universal phenomenon. In future research, we can continue to explore a more convincing explanation and a powerful predictor for the elusive return predictability in international stock markets.

Apart from academic perspective, this paper provides some important policy or practical implications in the context of international return predictability. First, the unexpected and extraordinary events of economic downturns have explosive impacts on stock market volatility and investors' expectations. This is linked to some possible explanations of fundamental uncertainty and time-varying risk premia. Second, the predictive power of lagged U.S. returns during recessions can help market participants to build feasible trading strategies and derive potential gains. Finally, the global financial system and economic conditions are of great concern to policymakers and investors because asset price volatility and information diffusion mainly originate from the U.S. stock market.

\section{References}

Aloui, R., Ben Aissa, M.S., Nguyen, D.K., 2011. Global financial crisis, extreme interdependences, and contagion effects: The role of economic structure? Journal of Banking and Finance 35, 130-141.

Andrei, D., Carlin, B., Hasler, M., 2019. Asset pricing with disagreement and uncertainty about the length of business cycles. Management Science 65(6), 2445-2945.

Ang, A., Bekaert, G., 2007. Stock return predictability: Is it there? Review of Financial Studies 20(3), 651-707.

Avramov, D., 2002. Stock return predictability and model uncertainty. Journal of Financial Economics 64, 423-458.

Aye, G. C., Balcilar, M., Gupta, R., 2017. International stock return predictability: Is the role of U.S. time-varying? Empirica 44(1), 121-146.

Bollerslev, T., Marrone, J., Xu, L., Zhou, H., 2013. Stock return predictability and variance risk premia: Statistical inference and international evidence. Journal of Financial and Quantitative Analysis 49(3), 633-661. 
Campbell, J.Y., Hentschel, L., 1992. No news is good news: An asymmetric model of changing volatility in stock returns. Journal of Financial Economics 31(3), 281-318.

Campbell, J.Y., Hamao, Y., 1992. Predicting stock returns in the United States and Japan: A study of long-term capital market integration. Journal of Finance 47, 63-49.

Carlin, B.I., Longstaff, F.A., Matoba, K., 2014. Disagreement and asset prices. Journal of Financial Economics 114(2), 226-238.

Cujean, J., Hasler, M., 2017. Why does return predictability concentrate in bad times? Journal of Finance 72(6), 2717-2758.

Dahlquist, M., Hasseltoft, H., 2013, International bond risk premia. Journal of International Economics 90, 19-32.

Estrella, A., Mishkin, F. S., 1998. Predicting U.S. recessions: Financial variables as leading indicators. Review of Economics and Statistics 80(1), 45-61.

Fama, E.F., French, K.R., 1989. Business conditions and expected returns on stocks and bonds. Journal of Financial Economics 25(1), 23-49.

Flannery, M.J., Protopapadakis, A.A., 2002. Macroeconomic factors do influence aggregate stock returns. Review of Financial Studies 15, 751-782.

Garcia, D., 2013. Sentiment during recessions. Journal of Finance 68(3), 1267-1300.

Griffin, J. M., 2002. Are the Fama and French factors global or country-specific? Review of Financial Studies 15, 783-803.

Hjalmarsson, E., 2010. Predicting global stock returns. Journal of Financial and Quantitative Analysis 45, 49-80.

Kandel, E., Pearson, N.D., 1995. Differential interpretation of public signals and trade in speculative markets. Journal of Political Economy 103(4), 831-872.

Karolyi, G.A., Stulz, R.M., 1996. Why do markets move together? An investigation of U.S.Japan stock return comovements. Journal of Finance 51, 951-986.

Kiefer, N.M., Vogelsang, T.J., 2005. A new asymptotic theory for heteroskedasticityautocorrelation robust tests. Econometric Theory 21(6), 1130-1164.

Kim, J.H., Shamsuddin, A., Lim, K.P., 2011. Stock return predictability and adaptive markets hypothesis: Evidence from century-long US data. Journal of Empirical Finance 18(5), 868-879.

Korajczyk, R.A., Viallet, C.J., 1989. An empirical investigation of international asset pricing. Review of Financial Studies 2, 553-585.

Lazarus, E., Lewis, D. J., Stock, J. H., Watson, M. W., 2018. HAR Inference: Recommendations for Practice. Journal of Business and Economic Statistics 36(4), 563564 
Lettau, M., Ludvigson, S., 2010. Measuring and modeling variation in the risk-return trade-off. In: Ait-Sahalia, Y., Hansen, L.P.(Eds.) Handbook of Financial Econometrics. Elsevier.

Lettau, M., Van Nieuwerburgh, S., 2008. Reconciling the return predictability evidence. Review of Financial Studies 21(4), 1607-1652.

Lin, W.L., Engle, R.F., Ito, T., 1994. Do bulls and bears move across borders? Transmission of international stock returns and volatility. Review of Financial Studies 7, 507-538.

Lo, A.W., 2004. The adaptive markets hypothesis: Market efficiency from an evolutionary perspective. Journal of Portfolio Management 30, 15-29.

Lo, A.W., 2005. Reconciling efficient markets with behavioral finance: The adaptive markets hypothesis. Journal of Investment Consulting 7, 21-44.

Lustig, H., Verdelhan, A., 2012. Business cycle variation in the risk-return trade-off. Journal of Monetary Economics 59, S35-S49.

Newey, W. K., West, K. D. 1987. A simple, positive semi-definite, heteroskedasticity and autocorrelation consistent covariance matrix. Econometrica 55(3), 703-708.

Nyberg, H., 2011. Risk-return tradeoff in U.S. stock returns over the business cycle. Journal of Financial and Quantitative Analysis 47(1), 137-158.

Nyberg, H., 2013. Predicting bear and bull stock markets with dynamic binary time series models. Journal of Banking and Finance 37(9), 3351-3363.

Nyberg, H., Pönkä, H., 2016. International sign predictability of stock returns: The role of the United States. Economic Modelling 58, 323-338.

Ozoguz, A., 2009. Good times or bad times? Investors' uncertainty and stock returns. Review of Financial Studies 22(11), 4377-4422.

Paye, B.S., Timmermann, A., 2006. Instability of return prediction models. Journal of Empirical Finance 13(3), 274-315.

Pesaran, M.H., Timmermann, A., 1995. Predictability of stock returns: Robustness and economic significance. Journal of Finance 50, 1201-1228.

Rapach, D., Wohar, M.E., Rangvid, J., 2005. Macro variables and international stock return predictability. International Journal of Forecasting 21, 137-166.

Rapach, D., Strauss, J.K., Zhou, G., 2013. International stock return predictability: What is the role of the United States? Journal of Finance 68 (4), 1633-1662.

Rodriguez, R., Restoy, F., Pena, J.I., 2002. Can output explain the predictability and volatility of stock returns? Journal of International Money and Finance 21, 163-182.

Schrimpf, A., 2010. International stock return predictability under model uncertainty. Journal of International Money and Finance 29, 1256-1282. 
Schwert, G.W., 1989. Why does stock market volatility change over time? Journal of Finance 44(5), 1115-1153.

Siliverstovs, B., 2017. International stock return predictability: on the role of the United States in bad and good times. Applied Economics Letters 24(11), 771-773.

Timmermann, A., 1993. How learning in financial markets generates excess volatility and predictability of excess returns. Quarterly Journal of Economics 108, 1135-1145.

Timmermann, A., 2008. Elusive return predictability. International Journal of Forecasting 24, $1-18$. 
Table 1

Summary statistics for the monthly stock returns across 17 developed countries over the full sample

\begin{tabular}{|c|c|c|c|c|c|c|c|c|c|c|c|c|c|}
\hline Country & Mean & Median & Std. Dev. & Skewness & Kurtosis & Min. & Max. & $\begin{array}{c}\text { Jarque- } \\
\text { Bera } \\
\text { stats. }\end{array}$ & $\rho(1)$ & $\begin{array}{l}\text { Ljung } \\
\text {-Box } \\
\left(Q_{20}\right)\end{array}$ & $\begin{array}{l}\text { Correlation } \\
\text { with US }\end{array}$ & $\begin{array}{c}10^{\text {th }} \\
\text { Percentile }\end{array}$ & $\begin{array}{c}90^{\text {th }} \\
\text { Percentile }\end{array}$ \\
\hline Australia & 0.007 & 0.010 & 0.070 & -1.482 & 13.254 & -0.589 & 0.227 & 8.414 & 0.007 & 13.463 & 0.578 & -0.064 & 0.085 \\
\hline Austria & 0.006 & 0.007 & 0.068 & -0.876 & 9.217 & -0.463 & 0.248 & 8.003 & 0.160 & 35.489 & 0.397 & -0.065 & 0.076 \\
\hline Belgium & 0.008 & 0.014 & 0.059 & -1.195 & 11.259 & -0.455 & 0.237 & 8.327 & 0.157 & 26.047 & 0.565 & -0.055 & 0.069 \\
\hline Canada & 0.007 & 0.010 & 0.056 & -0.846 & 6.568 & -0.314 & 0.193 & 6.879 & 0.060 & 18.625 & 0.747 & -0.057 & 0.072 \\
\hline Denmark & 0.010 & 0.012 & 0.055 & -0.470 & 5.408 & -0.297 & 0.221 & 5.334 & 0.061 & 33.503 & 0.494 & -0.053 & 0.074 \\
\hline France & 0.008 & 0.011 & 0.063 & -0.440 & 4.595 & -0.264 & 0.238 & 5.167 & 0.071 & 23.506 & 0.588 & -0.066 & 0.081 \\
\hline Germany & 0.007 & 0.009 & 0.063 & -0.620 & 4.918 & -0.279 & 0.213 & 5.920 & 0.027 & 20.459 & 0.579 & -0.063 & 0.079 \\
\hline Hong Kong & 0.011 & 0.012 & 0.095 & -0.531 & 10.792 & -0.570 & 0.631 & 8.617 & 0.084 & 28.091 & 0.432 & -0.084 & 0.114 \\
\hline Italy & 0.004 & 0.007 & 0.072 & -0.155 & 3.697 & -0.269 & 0.270 & 2.047 & 0.051 & 23.809 & 0.418 & -0.088 & 0.094 \\
\hline Japan & 0.007 & 0.007 & 0.059 & -0.025 & 3.865 & -0.215 & 0.217 & 2.787 & 0.105 & 37.547 & 0.387 & -0.064 & 0.079 \\
\hline Netherlands & 0.009 & 0.013 & 0.055 & -0.806 & 5.902 & -0.289 & 0.229 & 6.820 & 0.028 & 11.918 & 0.686 & -0.055 & 0.073 \\
\hline Norway & 0.008 & 0.010 & 0.078 & -0.786 & 6.129 & -0.406 & 0.227 & 6.694 & 0.126 & 30.349 & 0.556 & -0.076 & 0.104 \\
\hline Singapore & 0.008 & 0.010 & 0.079 & -0.512 & 9.335 & -0.533 & 0.427 & 8.223 & 0.107 & 25.854 & 0.556 & -0.080 & 0.088 \\
\hline Spain & 0.007 & 0.010 & 0.067 & -0.481 & 5.129 & -0.319 & 0.237 & 5.487 & 0.054 & 20.644 & 0.484 & -0.075 & 0.081 \\
\hline Sweden & 0.010 & 0.012 & 0.068 & -0.453 & 4.603 & -0.310 & 0.227 & 4.898 & 0.060 & 24.700 & 0.588 & -0.065 & 0.089 \\
\hline Switzerland & 0.009 & 0.011 & 0.051 & -0.383 & 4.436 & -0.194 & 0.220 & 5.116 & 0.063 & 23.483 & 0.588 & -0.054 & 0.069 \\
\hline U.K. & 0.008 & 0.010 & 0.060 & 0.345 & 8.941 & -0.243 & 0.447 & 7.317 & 0.078 & 28.925 & 0.608 & -0.063 & 0.070 \\
\hline
\end{tabular}

Notes: This table reports summary statistics of country (market) monthly returns covering the period from January 1970 to December 2019. All returns are U.S. dollar denominated. Jarque-Bera is the test of normality on returns. $\rho(1)$ refers to the first-order autocorrelation coefficients in monthly returns. Ljung-Box $\left(Q_{20}\right)$ denotes the Ljung-Box test statistic for serial correlation with 20 lags. We also report other information including the mean, median, minimum, maximum, standard deviation, skewness, kurtosis, the $10^{\text {th }}$ percentile and the $90^{\text {th }}$ percentile. In addition, we show the correlation coefficients of the 17 developed countries with the U.S. market returns during this sample period. 


\section{Table 2}

The predictive power on own country's future returns for lagged own country returns and lagged U.S. returns across 17 developed countries

\begin{tabular}{|c|c|c|c|c|c|c|c|c|c|c|}
\hline \multirow[b]{2}{*}{ Country } & \multicolumn{5}{|c|}{ Model (1) } & \multicolumn{5}{|c|}{ Model (2) } \\
\hline & const & t-stat. & $R_{i, t}^{\text {own }}$ & t-stat. & $R^{2}$ & const & t-stat & $R_{t}^{U S}$ & t-stat. & $R^{2}$ \\
\hline Australia & $0.007 * *$ & $(2.59)$ & 0.007 & $(0.13)$ & -0.002 & $0.006 * *$ & $(2.24)$ & $0.126 *$ & (1.93) & 0.005 \\
\hline Austria & $0.005 *$ & $(1.66)$ & $0.160 *$ & $(1.82)$ & 0.024 & 0.005 & $(1.30)$ & $0.184 * *$ & (2.09) & 0.012 \\
\hline Belgium & $0.007 * *$ & $(2.44)$ & $0.157 *$ & (1.91) & 0.023 & $0.008 * *$ & $(2.40)$ & 0.110 & (1.37) & 0.005 \\
\hline Canada & $0.007 * *$ & $(2.83)$ & 0.060 & $(1.20)$ & 0.002 & $0.006 * *$ & $(2.51)$ & $0.133 * *$ & (2.06) & 0.009 \\
\hline Denmark & $0.009 * *$ & $(3.37)$ & 0.061 & $(0.86)$ & 0.002 & $0.010 * *$ & $(3.35)$ & 0.047 & $(0.63)$ & 0.000 \\
\hline France & $0.007 * *$ & $(2.58)$ & 0.071 & $(1.42)$ & 0.003 & $0.007 * *$ & $(2.46)$ & 0.068 & (1.06) & 0.001 \\
\hline Germany & $0.007 * *$ & $(2.75)$ & 0.027 & $(0.58)$ & -0.001 & $0.007 * *$ & $(2.43)$ & $0.124 * *$ & (1.99) & 0.006 \\
\hline Hong Kong & $0.010 * *$ & $(2.70)$ & $0.084 * *$ & $(2.27)$ & 0.005 & $0.010 * *$ & $(2.45)$ & 0.133 & (1.51) & 0.002 \\
\hline Italy & 0.004 & $(1.23)$ & 0.051 & $(0.90)$ & 0.001 & 0.003 & $(0.96)$ & 0.108 & (1.29) & 0.003 \\
\hline Japan & $0.007 * *$ & $(2.43)$ & $0.105 * *$ & $(2.06)$ & 0.009 & $0.006 * *$ & (1.97) & $0.188 * *$ & (3.03) & 0.018 \\
\hline Netherlands & $0.009 * *$ & (3.67) & 0.028 & $(0.47)$ & -0.001 & $0.009 * *$ & (3.66) & 0.083 & (1.24) & 0.003 \\
\hline Norway & $0.007 * *$ & $(2.15)$ & $0.126 *$ & (1.89) & 0.014 & $0.007 *$ & (1.83) & 0.121 & (1.12) & 0.003 \\
\hline Singapore & $0.007 * *$ & $(2.32)$ & $0.107 * *$ & $(2.07)$ & 0.010 & $0.008 * *$ & (2.09) & 0.096 & (1.15) & 0.001 \\
\hline Spain & $0.006 * *$ & $(2.12)$ & 0.054 & (1.09) & 0.001 & $0.006^{*}$ & (1.94) & 0.081 & (1.11) & 0.001 \\
\hline Sweden & $0.009 * *$ & (3.08) & 0.060 & $(1.24)$ & 0.002 & $0.009 * *$ & $(2.93)$ & $0.141 *$ & (1.79) & 0.007 \\
\hline Switzerland & $0.008 * *$ & $(3.94)$ & $0.063 *$ & $(1.72)$ & 0.002 & $0.008 * *$ & (3.66) & $0.094 *$ & (1.70) & 0.005 \\
\hline U.K. & $0.007 * *$ & $(2.84)$ & 0.078 & $(1.37)$ & 0.004 & $0.007 * *$ & $(2.59)$ & 0.075 & (1.10) & 0.001 \\
\hline
\end{tabular}

Notes: Predictive regression model (1): $R_{i, t+1}^{\text {own }}=\alpha_{i}+\beta_{i} R_{i, t}^{\text {own }}+\varepsilon_{i, t+1}$, where $R_{i, t+1}^{\text {own }}$ is the one-month-ahead monthly market returns for country $i . R_{i, t}^{\text {own }}$ is defined as lagged own country returns in month $t$ for country $i$. Predictive regression model (2): $R_{i, t+1}^{\text {own }}=\alpha_{i}+\beta_{i} R_{t}^{U S}+\varepsilon_{i, t+1}$, where $R_{t}^{U S}$ denotes lagged U.S. return in month $t . \varepsilon_{i, t+1}$ is an error term. *, **, and *** denote significance at the $10 \%, 5 \%$, and 1\% levels, respectively. The sample period is from January 1970 to December 2019. Bold faces highlight significant estimates. Newey-West heteroskedasticity and autocorrelation consistent standard errors are used to compute robust $t$-statistics. 
Table 3

International return predictability using lagged own country returns and lagged U.S. returns across different sub-periods

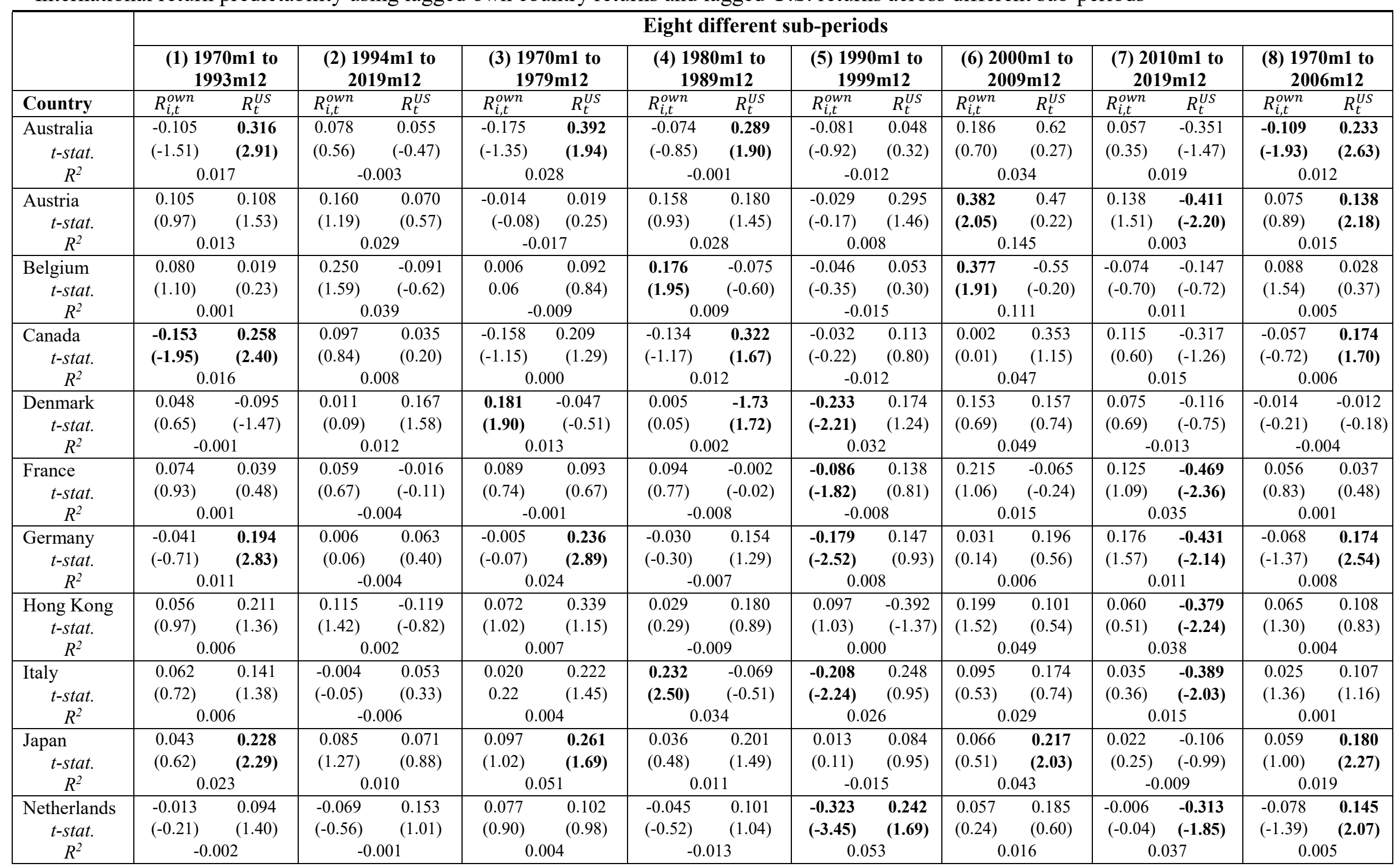




\begin{tabular}{|c|c|c|c|c|c|c|c|c|c|c|c|c|c|c|c|c|}
\hline $\begin{array}{c}\text { Norway } \\
t \text {-stat. }\end{array}$ & $\begin{array}{l}0.159 \\
(2.26)\end{array}$ & $\begin{array}{l}-0.075 \\
(-0.49)\end{array}$ & $\begin{array}{l}0.070 \\
(0.50)\end{array}$ & $\begin{array}{l}0.108 \\
(0.80)\end{array}$ & $\begin{array}{l}0.251 \\
(2.26)\end{array}$ & $\begin{array}{l}-0.117 \\
(-0.59)\end{array}$ & $\begin{array}{l}0.114 \\
(1.69)\end{array}$ & $\begin{array}{l}0.048 \\
(0.20)\end{array}$ & $\begin{array}{l}-0.098 \\
(-1.16)\end{array}$ & $\begin{array}{l}0.072 \\
(0.34)\end{array}$ & $\begin{array}{l}0.198 \\
(0.88)\end{array}$ & $\begin{array}{l}0.229 \\
(0.88)\end{array}$ & $\begin{array}{l}0.006 \\
(0.04)\end{array}$ & $\begin{array}{l}-0.274 \\
(-1.01)\end{array}$ & $\begin{array}{l}0.110 \\
(1.77)\end{array}$ & $\begin{array}{c}-0.007 \\
(-0.06)\end{array}$ \\
\hline$R^{2}$ & \multicolumn{2}{|c|}{0.014} & \multicolumn{2}{|c|}{0.008} & \multicolumn{2}{|c|}{0.039} & \multicolumn{2}{|c|}{0.000} & \multicolumn{2}{|c|}{-0.009} & \multicolumn{2}{|c|}{0.076} & \multicolumn{2}{|c|}{0.006} & \multicolumn{2}{|c|}{0.007} \\
\hline $\begin{array}{c}\text { Singapore } \\
t \text {-stat. }\end{array}$ & $\begin{array}{l}0.155 \\
(1.60)\end{array}$ & $\begin{array}{l}-0.052 \\
(-0.31)\end{array}$ & $\begin{array}{l}0.024 \\
(0.25)\end{array}$ & $\begin{array}{l}0.070 \\
(0.45)\end{array}$ & $\begin{array}{l}0.162 \\
(1.00)\end{array}$ & $\begin{array}{l}0.047 \\
(0.16)\end{array}$ & $\begin{array}{l}0.171 \\
(2.81)\end{array}$ & $\begin{array}{l}-0.163 \\
(-0.86)\end{array}$ & $\begin{array}{l}0.100 \\
(0.81)\end{array}$ & $\begin{array}{l}-0.182 \\
(-0.91)\end{array}$ & $\begin{array}{c}-0.106 \\
(-0.64)\end{array}$ & $\begin{array}{l}0.549 \\
(2.32)\end{array}$ & $\begin{array}{l}-0.026 \\
(-0.33)\end{array}$ & $\begin{array}{l}-0.273 \\
(-2.38)\end{array}$ & $\begin{array}{l}0.109 \\
(1.37)\end{array}$ & $\begin{array}{l}-0.007 \\
(-0.05)\end{array}$ \\
\hline$R^{2}$ & \multicolumn{2}{|c|}{0.014} & \multicolumn{2}{|c|}{-0.003} & \multicolumn{2}{|c|}{0.013} & \multicolumn{2}{|c|}{0.004} & \multicolumn{2}{|c|}{-0.008} & \multicolumn{2}{|c|}{0.064} & \multicolumn{2}{|c|}{0.028} & \multicolumn{2}{|c|}{0.007} \\
\hline $\begin{array}{c}\text { Spain } \\
\text { t-stat. } \\
R^{2}\end{array}$ & $\begin{array}{r}0.052 \\
(0.63) \\
0\end{array}$ & $\begin{array}{l}0.116 \\
(1.26) \\
4\end{array}$ & $\begin{array}{r}0.052 \\
(0.71)\end{array}$ & $\begin{array}{l}-0.036 \\
(-0.25) \\
05\end{array}$ & $\begin{array}{r}0.077 \\
(1.03) \\
-(\end{array}$ & $\begin{array}{l}0.037 \\
(0.22) \\
10\end{array}$ & $\begin{array}{l}0.121 \\
(0.88)\end{array}$ & $\begin{array}{c}0.084 \\
0.80 \\
6\end{array}$ & $\begin{array}{r}-0.154 \\
(-1.68) \\
0 .\end{array}$ & $\begin{array}{r}0.404 \\
2^{(1.78)}\end{array}$ & $\begin{array}{r}0.196 \\
(1.57) \\
0\end{array}$ & $\begin{array}{l}-0.046 \\
(-0.28) \\
13\end{array}$ & $\begin{array}{r}0.020 \\
(0.21) \\
0\end{array}$ & $\begin{array}{l}\mathbf{- 0 . 4 2 7} \\
\mathbf{( - 1 . 8 2 )} \\
26\end{array}$ & $\begin{array}{r}0.038 \\
(0.58) \\
0\end{array}$ & $\begin{array}{l}0.093 \\
(1.14)\end{array}$ \\
\hline $\begin{array}{r}\text { Sweden } \\
\text { t-stat. } \\
R^{2}\end{array}$ & $\begin{array}{r}-0.003 \\
(-0.06) \\
0\end{array}$ & $\begin{array}{l}\mathbf{0 . 2 0 8} \\
4^{(1.77)}\end{array}$ & $\begin{array}{l}0.069 \\
(0.66)\end{array}$ & $\begin{array}{l}-0.014 \\
(-0.10) \\
03\end{array}$ & $\begin{array}{r}-0.041 \\
(-0.71) \\
-(\end{array}$ & $\begin{array}{l}-0.001 \\
(-0.02) \\
16\end{array}$ & $\begin{array}{l}-0.014 \\
(-0.15)\end{array}$ & $\begin{array}{c}\mathbf{0 . 3 6 3} \\
\mathbf{1 . 8 8} \\
\end{array}$ & $\begin{array}{r}-0.064 \\
(-0.75) \\
0 .\end{array}$ & $\begin{array}{l}0.291 \\
3^{(1.41)}\end{array}$ & $\begin{array}{r}0.167 \\
(1.08) \\
0\end{array}$ & $\begin{array}{l}-0.025 \\
(-0.12) \\
09\end{array}$ & $\begin{array}{r}0.064 \\
(0.73) \\
0\end{array}$ & $\begin{array}{l}-0.404 \\
(-2.42) \\
30\end{array}$ & $\begin{array}{r}-0.026 \\
(-0.55) \\
0\end{array}$ & $\begin{array}{l}\mathbf{0 . 2 0 5} \\
0^{(2.03)}\end{array}$ \\
\hline $\begin{array}{c}\text { Switzerland } \\
\text { t-stat. } \\
R^{2}\end{array}$ & $\begin{array}{r}0.012 \\
(0.21) \\
-(\end{array}$ & $\begin{array}{l}0.089 \\
(1.21) \\
1\end{array}$ & $\begin{array}{l}0.045 \\
(0.49)\end{array}$ & $\begin{array}{l}0.057 \\
(0.40) \\
2^{(25}\end{array}$ & $\begin{array}{r}-0.031 \\
(-0.36) \\
-(\end{array}$ & $\begin{array}{l}0.172 \\
(1.40) \\
01\end{array}$ & $\begin{array}{r}0.070 \\
(0.77) \\
-\end{array}$ & $\begin{array}{l}0.046 \\
(0.46) \\
08\end{array}$ & $\begin{array}{r}-0.100 \\
(-1.20) \\
-0\end{array}$ & $\begin{array}{l}0.164 \\
(0.72) \\
4\end{array}$ & $\begin{array}{r}\mathbf{0 . 2 4 8} \\
(2.12) \\
0\end{array}$ & $\begin{array}{l}-0.013 \\
(-0.07) \\
41\end{array}$ & $\begin{array}{r}0.104 \\
(0.86) \\
0\end{array}$ & $\begin{array}{l}\mathbf{- 0 . 2 7 2} \\
(-1.66) \\
15\end{array}$ & $\begin{array}{r}0.014 \\
(0.27) \\
0\end{array}$ & $\begin{array}{l}0.094 \\
(1.23) \\
3^{(23)}\end{array}$ \\
\hline $\begin{array}{l}\text { U.K. } \\
\text { t-stat. } \\
R^{2}\end{array}$ & $\begin{array}{r}0.065 \\
(0.68) \\
-(\end{array}$ & $\begin{array}{l}0.011 \\
(0.08) \\
2^{(0.08}\end{array}$ & $\begin{array}{l}0.081 \\
(0.60)\end{array}$ & $\begin{array}{l}0.017 \\
(0.19)\end{array}$ & $\begin{array}{r}\mathbf{0 . 2 2 5} \\
(2.49) \\
0\end{array}$ & $\begin{array}{l}-0.125 \\
(-0.63) \\
25\end{array}$ & $\begin{array}{l}-0.216 \\
(-2.52)\end{array}$ & $\begin{array}{l}0.270 \\
(1.64) \\
19\end{array}$ & $\begin{array}{r}-0.087 \\
(-1.57) \\
-0 .\end{array}$ & $\begin{array}{l}0.060 \\
(0.55) \\
2^{(0.55)}\end{array}$ & $\begin{array}{r}\mathbf{0 . 3 9 5} \\
(1.73) \\
0\end{array}$ & $\begin{array}{l}-0.090 \\
(-0.46) \\
92\end{array}$ & $\begin{array}{r}-0.033 \\
(-0.24) \\
0\end{array}$ & $\begin{array}{l}-0.235 \\
(-1.27) \\
33\end{array}$ & $\begin{array}{r}0.057 \\
(0.66) \\
0\end{array}$ & $\begin{array}{l}0.016 \\
(0.15) \\
0^{2}\end{array}$ \\
\hline
\end{tabular}

Notes: Regression equation (3): $R_{i, t+1}^{o w n}=\alpha_{i}+\beta_{i} R_{i, t}^{o w n}+\gamma_{i} R_{t}^{U S}+\varepsilon_{i, t+1}$, where $R_{i, t+1}^{o w n}$ is the one-month-ahead monthly market returns for country $i . R_{i, t}^{o w n}$ is defined as lagged own country returns in month $t$ for country $i$. $R_{t}^{U S}$ denotes lagged U.S. return in month $t . \varepsilon_{i, t+1}$ is an error term. We divide the entire sample period into eight sub-periods based on the inclusion of recession and expansion periods that are observed in the NBER business cycles. For brevity, we only report the regression coefficients, $t$-statistic and $R^{2}$. The $t$-statistic (in parentheses) and coefficients that are statistically significant at the $10 \%$ level or more are shown in bold type. 
Table 4

The predictive relationship between the own country's future returns and lagged U.S. returns with the NBER business cycles

Panel A: The interaction effect of lagged U.S. returns with the recessions

\begin{tabular}{|c|c|c|c|c|c|c|c|}
\hline Country & const & t-stat & $R_{t}^{U S}$ & t-stat & $R_{t}^{U S} \times R e c_{t}$ & t-stat & $R^{2}$ \\
\hline Australia & $0.007 * *$ & $(2.86)$ & 0.025 & $(0.43)$ & $0.351 * *$ & (2.90) & 0.013 \\
\hline Austria & $0.006^{*}$ & (1.66) & 0.095 & (1.39) & 0.308 & (1.59) & 0.018 \\
\hline Belgium & $0.009 * *$ & (2.93) & 0.013 & $(0.20)$ & $0.338 * *$ & (2.14) & 0.016 \\
\hline Canada & $0.007 * *$ & (3.16) & 0.023 & $(0.49)$ & $0.383 * *$ & (2.22) & 0.025 \\
\hline Denmark & $0.011 * *$ & $(3.85)$ & -0.041 & $(-0.71)$ & $0.307 *$ & (1.93) & 0.010 \\
\hline France & $0.008 * *$ & $(2.79)$ & -0.010 & $(-0.16)$ & $0.272^{* *}$ & (2.66) & 0.006 \\
\hline Germany & $0.007 * *$ & $(2.75)$ & 0.035 & $(0.56)$ & $\mathbf{0 . 3 0 9} * *$ & (3.02) & 0.014 \\
\hline Hong Kong & $0.011^{* *}$ & (2.64) & 0.042 & $(0.41)$ & $0.316 *$ & (1.68) & 0.005 \\
\hline Italy & 0.005 & $(1.43)$ & -0.041 & $(-0.50)$ & $0.520 * *$ & (4.40) & 0.021 \\
\hline Japan & $0.007 * *$ & $(2.41)$ & 0.079 & $(1.28)$ & $\mathbf{0 . 3 7 9} * *$ & (3.47) & 0.033 \\
\hline Netherlands & $0.010^{* *}$ & (4.31) & -0.019 & $(-0.30)$ & $0.353 * *$ & (3.23) & 0.017 \\
\hline Norway & $0.008^{* *}$ & $(2.14)$ & 0.019 & $(0.17)$ & 0.352 & (1.54) & 0.009 \\
\hline Singapore & $0.009 * *$ & $(2.54)$ & -0.052 & $(-0.61)$ & $0.512 * *$ & (2.96) & 0.016 \\
\hline Spain & $0.007 * *$ & $(2.28)$ & -0.013 & $(-0.16)$ & $0.323 * *$ & (2.42) & 0.008 \\
\hline Sweden & $0.010 * *$ & (3.14) & 0.065 & $(0.73)$ & 0.265 & (1.59) & 0.011 \\
\hline Switzerland & $0.009 * *$ & (3.94) & 0.030 & $(0.47)$ & $0.223 * *$ & (2.35) & 0.011 \\
\hline U.K. & $0.008^{* *}$ & (3.20) & -0.041 & $(-0.68)$ & $0.402 * *$ & (3.18) & 0.017 \\
\hline
\end{tabular}

Panel B: The interaction effect of lagged U.S. returns with the recessions including four different predictors

\begin{tabular}{|c|c|c|c|c|c|c|c|c|c|c|c|c|c|c|c|}
\hline Country & const & t-stat & $R_{t}^{U S}$ & t-stat & $R_{t}^{U S} \times R e c_{t}$ & t-stat & $R_{i, t}^{o w}$ & t-stat & $D Y_{t}$ & t-stat & $T B_{t}$ & t-stat & $d \mathrm{dOil}_{t}$ & t-stat & $R^{2}$ \\
\hline Australia & 0.001 & $(0.12)$ & 0.089 & $(1.10)$ & $0.366 * *$ & $(2.87)$ & -0.082 & $(-1.27)$ & 0.484 & $(1.63)$ & -1.963 & $(-1.39)$ & 0.027 & $(0.90)$ & 0.014 \\
\hline Austria & 0.001 & $(0.13)$ & 0.032 & $(0.40)$ & $0.250 *$ & (1.70) & 0.122 & $(1.52)$ & 0.255 & $(0.92)$ & -0.753 & $(-0.50)$ & 0.019 & $(0.83)$ & 0.026 \\
\hline Belgium & -0.002 & $(-0.29)$ & -0.089 & $(-1.05)$ & $0.292 * *$ & $(2.20)$ & $0.148^{*}$ & $(1.79)$ & $0.631^{* *}$ & $(2.46)$ & $-2.056^{*}$ & $(-1.70)$ & -0.006 & $(-0.23)$ & 0.033 \\
\hline Canada & 0.001 & $(0.16)$ & 0.092 & $(0.97)$ & $0.401 * *$ & (2.18) & -0.079 & $(-0.97)$ & 0.343 & $(0.99)$ & -1.013 & $(-0.74)$ & 0.025 & $(1.08)$ & 0.027 \\
\hline Denmark & 0.008 & $(1.38)$ & -0.074 & $(-1.02)$ & $0.297 *$ & (1.94) & 0.054 & $(0.82)$ & 0.162 & $(0.65)$ & -0.721 & $(-0.64)$ & -0.002 & $(-0.08)$ & 0.006 \\
\hline France & -0.001 & $(-0.13)$ & -0.064 & $(-0.74)$ & $0.251 * *$ & (2.35) & 0.065 & $(1.07)$ & $0.543^{*}$ & $(1.65)$ & -1.679 & $(-1.12)$ & -0.006 & $(-0.20)$ & 0.007 \\
\hline Germany & 0.000 & $(-0.03)$ & 0.072 & $(0.92)$ & $0.300 * *$ & (2.58) & -0.037 & $(-0.78)$ & 0.423 & $(1.40)$ & -1.065 & $(-0.85)$ & -0.041 & $(-1.44)$ & 0.015 \\
\hline Hong Kong & 0.000 & $(-0.04)$ & -0.012 & $(-0.10)$ & 0.306 & (1.63) & 0.065 & $(1.27)$ & 0.701 & $(1.40)$ & -2.335 & $(-1.46)$ & -0.013 & $(-0.32)$ & 0.006 \\
\hline Italy & 0.003 & $(0.38)$ & -0.043 & $(-0.50)$ & $0.517 * *$ & $(4.09)$ & 0.025 & $(0.43)$ & 0.004 & $(0.01)$ & 0.553 & $(0.36)$ & $-0.086^{*}$ & $(-1.83)$ & 0.030 \\
\hline Japan & -0.006 & $(-0.94)$ & 0.056 & $(0.92)$ & $0.365 * *$ & (3.38) & 0.048 & $(0.88)$ & $0.799 * *$ & $(2.58)$ & $-2.515^{* *}$ & $(-2.20)$ & 0.001 & $(0.06)$ & 0.042 \\
\hline Netherlands & -0.002 & $(-0.28)$ & 0.020 & $(0.24)$ & $0.349 * *$ & (2.85) & -0.041 & $(-0.70)$ & $0.628 * *$ & $(2.67)$ & -1.593 & $(-1.35)$ & -0.024 & $(-1.18)$ & 0.023 \\
\hline Norway & 0.004 & $(0.44)$ & -0.092 & $(-0.71)$ & 0.315 & $(1.52)$ & $0.120^{*}$ & $(1.67)$ & 0.191 & $(0.53)$ & -0.294 & $(-0.22)$ & 0.006 & $(0.17)$ & 0.013 \\
\hline Singapore & -0.004 & $(-0.41)$ & -0.136 & $(-1.15)$ & $0.473 * *$ & $(2.65)$ & 0.091 & $(1.20)$ & $0.819^{*}$ & $(1.95)$ & -2.792 & $(-1.62)$ & 0.006 & $(0.28)$ & 0.023 \\
\hline Spain & 0.011 & $(1.43)$ & -0.032 & $(-0.39)$ & $0.347 * *$ & (2.70) & 0.032 & $(0.60)$ & -0.336 & $(-0.86)$ & 1.354 & $(0.95)$ & -0.028 & $(-0.85)$ & 0.007 \\
\hline Sweden & -0.001 & $(-0.07)$ & 0.062 & $(0.56)$ & 0.241 & (1.41) & 0.011 & $(0.20)$ & 0.527 & $(1.16)$ & -1.139 & $(-0.68)$ & -0.036 & $(-0.90)$ & 0.011 \\
\hline Switzerland & 0.003 & $(0.53)$ & 0.021 & $(0.26)$ & $0.210 * *$ & $(2.07)$ & 0.017 & $(0.35)$ & $0.459 * *$ & $(2.03)$ & -1.766 & $(-1.63)$ & -0.021 & $(-1.02)$ & 0.012 \\
\hline U.K. & -0.005 & $(-0.99)$ & -0.081 & $(-0.85)$ & $0.366 * *$ & $(2.67)$ & 0.051 & $(0.67)$ & $0.696^{* *}$ & $(2.74)$ & -1.634 & $(-1.47)$ & 0.008 & $(0.36)$ & 0.021 \\
\hline
\end{tabular}


Notes: Panel A reports the predictive results when considering the aggregate state of the U.S. economy during recessions. Regression model (4) $: R_{i, t+1}^{\text {own }}=\alpha_{i}+\beta_{i} R_{t}^{U S}+$ $\gamma_{i} R_{t}^{U S} \times R e c_{t}+\varepsilon_{i, t+1}$, where $R_{i, t+1}^{o w n}$ is the one-month-ahead monthly market returns for country $i . R_{t}^{U S}$ denotes lagged U.S. return in month $t . R e c_{t}$ is an indicator variable that takes a value of one if the U.S. economy is in an NBER recession period in month $t$, and 0 otherwise. Panel B also presents the predictive power of the lagged own country returns $\left(R_{i, t}^{o w n}\right)$, the dividend yield of the U.S. market $\left(D Y_{t}\right)$, U.S. three-month Treasury-bill rate $\left(T B_{t}\right)$ and changes in oil prices $\left(d O i l_{t}\right)$ using Model $(5)$. The sample period is from January 1970 to December $2019 . * * *$, and $* * *$ denote significance at the $10 \%, 5 \%$, and $1 \%$ levels, respectively. Bold faces highlight significant estimates. Newey-West heteroskedasticity and autocorrelation consistent standard errors are used to compute robust $t$-statistics. 
Table 5

The predictive relationship between the own country's future returns and lagged U.S. returns with negative values or extreme returns

Panel A: The interaction effect of lagged U.S. returns with negative values

\begin{tabular}{lccccccccc}
\hline Country & const & t-stat & $R_{i, t}^{\text {own }}$ & t-stat & $R_{t}^{U S}$ & t-stat & $R_{t}^{U S} \times N e g_{t}$ & t-stat & $R^{2}$ \\
\hline Australia & 0.004 & $(1.03)$ & -0.054 & $(-0.83)$ & $0.224^{*}$ & $(1.81)$ & -0.094 & $(-0.41)$ & 0.004 \\
Austria & 0.007 & $(1.55)$ & 0.130 & $(1.45)$ & 0.038 & $(0.38)$ & 0.130 & $(0.69)$ & 0.025 \\
Belgium & $0.009^{* *}$ & $(2.23)$ & $0.158^{*}$ & $(1.73)$ & -0.071 & $(-0.66)$ & 0.119 & $(0.68)$ & 0.021 \\
Canada & $0.006^{*}$ & $(1.87)$ & -0.039 & $(-0.54)$ & 0.164 & $(1.24)$ & 0.014 & $(0.08)$ & 0.006 \\
Denmark & $0.014^{* *}$ & $(3.14)$ & 0.047 & $(0.67)$ & -0.118 & $(-1.15)$ & 0.270 & $(1.59)$ & 0.004 \\
France & $0.009^{* *}$ & $(2.38)$ & 0.063 & $(1.02)$ & -0.048 & $(-0.48)$ & 0.123 & $(0.84)$ & 0.001 \\
Germany & $0.010^{* *}$ & $(2.48)$ & -0.045 & $(-0.92)$ & 0.058 & $(0.54)$ & 0.205 & $(1.09)$ & 0.005 \\
Hong Kong & $0.014^{* *}$ & $(2.49)$ & 0.066 & $(1.38)$ & -0.058 & $(-0.34)$ & 0.257 & $(0.89)$ & 0.004 \\
Italy & 0.004 & $(0.90)$ & 0.028 & $(0.47)$ & 0.071 & $(0.58)$ & 0.035 & $(0.21)$ & 0.000 \\
Japan & $0.008^{*}$ & $(1.89)$ & 0.056 & $(1.01)$ & 0.090 & $(0.74)$ & 0.137 & $(0.74)$ & 0.019 \\
Netherlands & $0.013^{* *}$ & $(3.85)$ & -0.044 & $(-0.69)$ & 0.005 & $(0.06)$ & $\mathbf{0 . 2 2 9} *$ & $(\mathbf{1 . 7 0 )}$ & 0.003 \\
Norway & $0.014^{* *}$ & $(3.02)$ & 0.117 & $(1.63)$ & -0.211 & $(-1.47)$ & $\mathbf{0 . 4 3 1} *$ & $(\mathbf{1 . 9 4 )}$ & 0.017 \\
Singapore & 0.007 & $(1.26)$ & 0.114 & $(1.51)$ & 0.008 & $(0.05)$ & -0.053 & $(-0.19)$ & 0.007 \\
Spain & 0.005 & $(1.14)$ & 0.039 & $(0.70)$ & 0.083 & $(0.73)$ & -0.062 & $(-0.32)$ & -0.001 \\
Sweden & $0.011^{* *}$ & $(2.62)$ & 0.007 & $(0.13)$ & 0.086 & $(0.68)$ & 0.096 & $(0.54)$ & 0.004 \\
Switzerland & $0.011^{* *}$ & $(3.80)$ & 0.015 & $(0.30)$ & -0.010 & $(-0.12)$ & 0.186 & $(1.49)$ & 0.004 \\
U.K. & $0.008^{* *}$ & $(2.30)$ & 0.069 & $(0.85)$ & -0.026 & $(-0.18)$ & 0.085 & $(0.51)$ & 0.002 \\
\hline
\end{tabular}

Panel B: The interaction effect of lagged U.S. returns with the lowest $10 \%$ quantile of returns

\begin{tabular}{|c|c|c|c|c|c|c|c|c|c|}
\hline Country & const & t-stat & $\overline{R_{i, t}^{\text {own }}}$ & t-stat & $R_{t}^{U S}$ & t-stat & $R_{t}^{U S} \times \operatorname{Low}_{t}^{10}$ & t-stat & $\overline{R^{2}}$ \\
\hline Australia & 0.004 & $(1.36)$ & -0.050 & $(-0.79)$ & $0.236 * *$ & $(2.21)$ & -0.153 & $(-0.81)$ & 0.005 \\
\hline Austria & 0.005 & (1.61) & 0.132 & $(1.49)$ & 0.077 & $(0.96)$ & 0.061 & $(0.39)$ & 0.025 \\
\hline Belgium & $0.010 * *$ & $(2.97)$ & $0.152 *$ & $(1.72)$ & -0.089 & $(-0.98)$ & 0.201 & $(1.26)$ & 0.024 \\
\hline Canada & $0.007 * *$ & (2.63) & -0.042 & $(-0.58)$ & 0.145 & $(1.27)$ & 0.068 & $(0.51)$ & 0.007 \\
\hline Denmark & $0.012 * *$ & (3.61) & 0.045 & $(0.65)$ & -0.069 & $(-0.89)$ & 0.212 & $(1.55)$ & 0.004 \\
\hline France & $0.009 * *$ & $(2.81)$ & 0.061 & (0.99) & -0.058 & $(-0.69)$ & 0.179 & $(1.37)$ & 0.003 \\
\hline Germany & $0.008^{* *}$ & $(2.81)$ & -0.045 & $(-0.93)$ & 0.096 & $(1.22)$ & 0.159 & $(1.09)$ & 0.005 \\
\hline Hong Kong & $0.012 * *$ & $(2.78)$ & 0.067 & $(1.40)$ & -0.013 & $(-0.09)$ & 0.202 & $(0.83)$ & 0.004 \\
\hline Italy & 0.004 & $(1.20)$ & 0.027 & $(0.44)$ & 0.056 & $(0.54)$ & 0.084 & $(0.59)$ & 0.000 \\
\hline Japan & $0.008^{* *}$ & (2.53) & 0.053 & $(0.93)$ & 0.074 & $(0.82)$ & 0.209 & $(1.42)$ & 0.022 \\
\hline Netherlands & $0.012 * *$ & (4.54) & -0.050 & $(-0.80)$ & 0.025 & $(0.34)$ & $0.244 * *$ & $(2.03)$ & 0.006 \\
\hline Norway & $0.011^{* *}$ & (3.01) & 0.114 & (1.64) & -0.138 & $(-1.16)$ & $0.352 * *$ & $(2.05)$ & 0.018 \\
\hline Singapore & $0.009 * *$ & $(2.30)$ & 0.107 & (1.42) & -0.055 & $(-0.42)$ & 0.104 & $(0.45)$ & 0.007 \\
\hline Spain & 0.005 & (1.62) & 0.040 & $(0.70)$ & 0.075 & $(0.89)$ & -0.057 & $(-0.35)$ & -0.001 \\
\hline Sweden & $0.011 * *$ & (3.42) & 0.001 & $(0.02)$ & 0.068 & (0.64) & 0.176 & (1.14) & 0.006 \\
\hline Switzerland & $0.011^{* *}$ & $(4.20)$ & 0.012 & $(0.24)$ & -0.004 & $(-0.05)$ & $0.218 *$ & $(1.92)$ & 0.008 \\
\hline U.K. & $0.009 * *$ & $(3.36)$ & 0.065 & $(0.78)$ & -0.061 & $(-0.51)$ & 0.199 & (1.53) & 0.005 \\
\hline
\end{tabular}

Notes: Panels A reports the predictive power of lagged U.S. returns with negative values based on Model (6): $R_{i, t+1}^{\text {own }}=\alpha_{i}+\beta_{i} R_{i, t}^{\text {own }}+\gamma_{i} R_{t}^{U S}+\delta_{i} R_{t}^{U S} \times N e g_{t}+\varepsilon_{i, t+1}$. We also divide U.S. returns into different quantiles and focus only on the lowest extreme returns. In Model (7), we replace negative returns with the lowest $10 \%$ quantile of returns. $\mathrm{Neg}_{t}$ and $\operatorname{Low}_{t}^{10}$ are dummy variables that take the value of one if U.S. returns are negative values and the lowest $10 \%$ quantile of returns respectively in month $t$, and zero otherwise. $R_{i, t+1}^{o w n}$ is the one-month-ahead monthly market returns for country $i . R_{i, t}^{o w n}$ is defined as lagged own country returns in month $t$ for country $i . R_{t}^{U S}$ denotes lagged U.S. return in month $t$. The sample period is from January 1970 to December 2019. *, **, and *** denote significance at the $10 \%, 5 \%$, and $1 \%$ levels, respectively. Bold faces highlight significant estimates. Newey-West heteroskedasticity and autocorrelation consistent standard errors are used to compute robust $t$-statistics. 
Table 6

The predictive power between the own country's future returns and lagged country returns for 26 developing countries

\begin{tabular}{|c|c|c|c|c|c|c|c|c|c|c|c|c|c|c|c|c|}
\hline \multicolumn{8}{|c|}{$\begin{array}{l}\text { Panel A: The predictive ability between the own country's future returns and } \\
\text { lagged country returns }\end{array}$} & \multicolumn{9}{|c|}{ Panel B: The interaction effect of lagged U.S. returns with NBER recessions } \\
\hline Country & const & t-stat & $R_{i, t}^{\text {own }}$ & t-stat & $R_{t}^{U S}$ & t-stat & $R^{2}$ & const & t-stat & $R_{i, t}^{\text {own }}$ & t-stat & $R_{t}^{U S}$ & t-stat & $R_{t}^{U S} \times \operatorname{Rec}_{t}$ & t-stat & $R^{2}$ \\
\hline Finland & $0.008^{*}$ & $(1.73)$ & $0.252 * *$ & $(3.78)$ & $-0.314 *$ & $(-1.75)$ & 0.036 & $0.009 * *$ & $(2.07)$ & $0.239 * *$ & $(3.53)$ & $-0.398 * *$ & $(-2.57)$ & $0.425 *$ & (1.73) & 0.040 \\
\hline New Zealand & 0.005 & $(1.26)$ & -0.057 & $(-0.85)$ & 0.172 & (1.49) & 0.004 & 0.006 & $(1.57)$ & -0.073 & $(-1.18)$ & 0.106 & $(0.86)$ & $0.332 * *$ & (2.49) & 0.009 \\
\hline Argentina & 0.007 & $(0.87)$ & 0.018 & $(0.46)$ & 0.282 & (1.24) & 0.003 & 0.011 & $(1.52)$ & 0.012 & $(0.33)$ & -0.032 & $(-0.16)$ & $1.357 * *$ & (3.64) & 0.027 \\
\hline Brazil & 0.010 & $(1.50)$ & -0.113 & $(-1.03)$ & 0.214 & $(0.88)$ & 0.006 & $0.014 * *$ & $(2.18)$ & -0.121 & $(-1.10)$ & -0.073 & $(-0.37)$ & $1.264 * *$ & $(5.08)$ & 0.027 \\
\hline Chile & $0.009 * *$ & $(2.36)$ & $0.123^{*}$ & (1.78) & -0.037 & $(-0.35)$ & 0.008 & $0.011 * *$ & $(2.93)$ & $0.111^{*}$ & $(1.77)$ & $-0.195 * *$ & $(-2.00)$ & $0.705 * *$ & $(4.23)$ & 0.036 \\
\hline Greece & -0.003 & $(-0.40)$ & 0.053 & (1.13) & 0.219 & $(1.29)$ & 0.008 & -0.001 & $(-0.18)$ & 0.040 & $(0.88)$ & 0.107 & $(0.64)$ & $0.537 * *$ & (2.20) & 0.012 \\
\hline Indonesia & 0.004 & $(0.54)$ & $0.128 * *$ & (1.97) & 0.386 & $(1.50)$ & 0.040 & 0.005 & $(0.79)$ & $0.124^{*}$ & (1.93) & 0.254 & $(0.83)$ & 0.580 & $(1.60)$ & 0.044 \\
\hline Ireland & 0.002 & $(0.56)$ & 0.059 & $(0.46)$ & 0.112 & (1.33) & 0.009 & 0.004 & $(1.17)$ & 0.027 & $(0.26)$ & -0.013 & $(-0.13)$ & $0.665^{* *}$ & (3.54) & 0.039 \\
\hline Jordan & 0.000 & $(0.04)$ & $0.111^{*}$ & (1.84) & $0.172 *$ & (1.84) & 0.031 & 0.001 & $(0.45)$ & 0.085 & $(1.55)$ & 0.082 & $(1.29)$ & $0.405^{*}$ & (1.76) & 0.046 \\
\hline Korea & 0.004 & $(0.74)$ & 0.019 & $(0.31)$ & 0.112 & $(0.66)$ & -0.002 & 0.005 & $(1.00)$ & 0.011 & $(0.18)$ & 0.030 & $(0.18)$ & 0.382 & $(1.61)$ & 0.000 \\
\hline Malaysia & 0.004 & $(0.94)$ & 0.146 & $(1.55)$ & 0.057 & $(0.47)$ & 0.021 & 0.005 & $(1.26)$ & 0.147 & $(1.53)$ & -0.050 & $(-0.38)$ & $0.449 * *$ & (2.57) & 0.029 \\
\hline Mexico & $0.010 * *$ & $(2.14)$ & 0.097 & $(1.22)$ & -0.026 & $(-0.20)$ & 0.003 & $0.013^{* *}$ & $(2.73)$ & 0.086 & $(1.08)$ & $-0.212 *$ & $(-1.90)$ & $0.842 * *$ & $(4.86)$ & 0.029 \\
\hline Philippines & 0.005 & $(1.17)$ & $0.185^{* *}$ & $(2.83)$ & -0.030 & $(-0.23)$ & 0.027 & 0.007 & $(1.58)$ & $0.175^{* *}$ & $(2.60)$ & -0.169 & $(-1.34)$ & $0.630 * *$ & (2.70) & 0.042 \\
\hline Portugal & 0.001 & $(0.22)$ & 0.061 & (1.02) & 0.112 & $(0.95)$ & 0.008 & 0.001 & $(0.40)$ & 0.055 & $(0.94)$ & 0.065 & $(0.52)$ & 0.221 & $(1.16)$ & 0.009 \\
\hline Taiwan & 0.004 & $(0.95)$ & 0.104 & $(1.60)$ & 0.041 & $(0.32)$ & 0.008 & 0.006 & $(1.25)$ & 0.088 & $(1.39)$ & -0.063 & $(-0.48)$ & $0.503 * *$ & (2.26) & 0.013 \\
\hline Thailand & 0.006 & $(1.09)$ & 0.051 & $(0.67)$ & 0.014 & $(0.06)$ & -0.002 & $0.009^{*}$ & $(1.90)$ & 0.040 & $(0.53)$ & -0.246 & $(-1.18)$ & $1.157^{* *}$ & (4.11) & 0.035 \\
\hline Turkey & 0.002 & $(0.21)$ & 0.038 & $(0.62)$ & $0.392 * *$ & (2.24) & 0.011 & 0.002 & $(0.28)$ & 0.035 & $(0.57)$ & $0.353 *$ & $(1.72)$ & 0.177 & $(0.50)$ & 0.009 \\
\hline China & 0.003 & $(0.58)$ & $0.142 * *$ & $(2.38)$ & -0.211 & $(-1.13)$ & 0.009 & 0.004 & $(0.70)$ & $0.138 * *$ & $(2.35)$ & -0.266 & $(-1.17)$ & 0.253 & $(1.04)$ & 0.008 \\
\hline Colombia & 0.006 & $(1.21)$ & $0.117 * *$ & $(2.05)$ & 0.203 & $(1.31)$ & 0.024 & 0.008 & $(1.37)$ & $0.102 *$ & $(1.71)$ & 0.113 & $(0.68)$ & 0.433 & $(1.26)$ & 0.028 \\
\hline India & 0.006 & $(1.18)$ & 0.060 & $(1.12)$ & 0.116 & $(0.87)$ & 0.004 & 0.008 & $(1.59)$ & 0.024 & $(0.49)$ & -0.007 & $(-0.06)$ & $0.666^{* *}$ & (2.80) & 0.020 \\
\hline Israel & 0.003 & $(0.77)$ & 0.003 & $(0.06)$ & 0.096 & $(0.91)$ & -0.002 & 0.004 & (1.14) & 0.006 & $(0.12)$ & -0.007 & $(-0.07)$ & $0.434 * *$ & (3.31) & 0.007 \\
\hline Pakistan & 0.004 & $(0.59)$ & 0.038 & $(0.60)$ & 0.018 & $(0.14)$ & -0.005 & 0.004 & $(0.61)$ & 0.037 & $(0.59)$ & 0.027 & $(0.21)$ & -0.039 & $(-0.11)$ & -0.008 \\
\hline Peru & $0.012 * *$ & $(2.19)$ & -0.014 & $(-0.25)$ & 0.032 & $(0.33)$ & -0.006 & $0.012 * *$ & $(2.41)$ & -0.018 & $(-0.32)$ & -0.017 & $(-0.19)$ & 0.226 & $(0.96)$ & -0.007 \\
\hline Poland & 0.008 & $(1.06)$ & 0.102 & $(1.15)$ & -0.157 & $(-0.73)$ & 0.002 & 0.010 & $(1.37)$ & 0.092 & $(1.05)$ & -0.301 & $(-1.52)$ & $0.682 * *$ & $(2.32)$ & 0.009 \\
\hline South Africa & $0.007 *$ & $(1.77)$ & -0.027 & $(-0.47)$ & 0.013 & $(0.11)$ & -0.006 & $0.009 * *$ & $(2.16)$ & -0.042 & $(-0.73)$ & -0.080 & $(-0.67)$ & $0.466 * *$ & $(2.67)$ & 0.002 \\
\hline Sri Lanka & 0.001 & $(0.24)$ & 0.040 & $(0.86)$ & $0.324^{*}$ & (1.82) & 0.020 & 0.003 & $(0.56)$ & 0.028 & $(0.66)$ & 0.183 & $(1.22)$ & 0.632 & $(1.43)$ & 0.032 \\
\hline
\end{tabular}

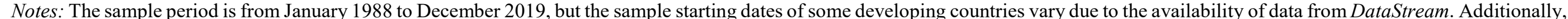

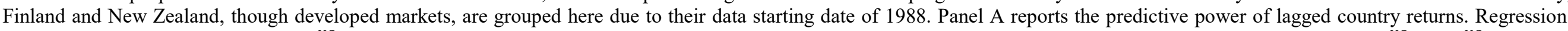

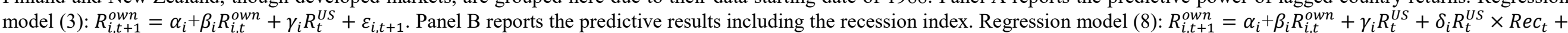

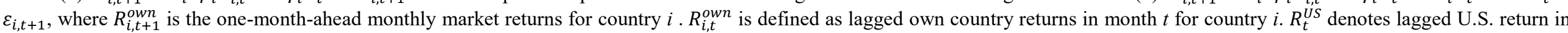

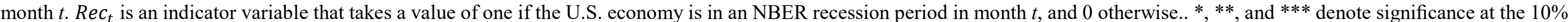

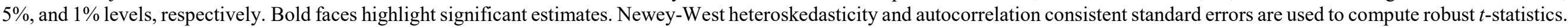

